\title{
Time and Memory in Pinter's absurdist play Betrayal
}

\author{
Ms. Nabamita Das \\ (Department of Humanities \& Social Sciences, Don Bosco College of Engineering and Technology, India)
}

\begin{abstract}
Modernism is a movement which aims at defying the established norms and conventions. It challenges the coherence and harmony in the structure of the literary works. Modern drama departs from such conventionality of the well-made plays of the classics and other realistic dramas. Harold Pinter's Betrayal is one such play of the modern theatre. Pinter narrates a story of betrayal in an unconventional way. Harold Pinter shows that men are betrayed not only by men, but by time. Such betrayal is a recurring theme in the play. The paper is an attempt to explain how the truth about its characters is approached by reversing the chronological order in which their actions are viewed. Recollection of events on the basis of memory leads one to recall them retrospectively in a non-chronological order. The paper further highlights how the play is a rendering of the author's memory.
\end{abstract}

Keywords- Absurdism, betrayal, chronology, memory, time

\section{Introduction}

Absurdism is an idea commonly associated with the philosophy of Existentialism which took birth in the $19^{\text {th }}$ century, mainly through the influence of Soren Kierkegaard. Existential philosophy often described religion as absurd because it could not be justified on rational principles; rather it was considered as based on what Kierkegaard called "a leap of faith". In their discussions on consciousness, Martin Heidegger and Jean Paul Sartre described the human consciousness as facing an apparently absurd world - absurd because it finds itself at the crossroads of Being and Nothingness baffled by the meaninglessness of the human condition. Most Existentialists believed that human beings are abandoned in the world and that the world does not give meaning to individuals while some of them argued that one must make meaning for oneself, others concluded that the world is 'absurd' and hence human existence is condemned to be devoid of meaning and purpose. As Eugene Ionesco, a French playwright of the absurd has put it: "Cut off from his religious, metaphysical, and transcendental roots, man is lost; all his actions become senseless, absurd, and useless."'[1] The ideas of absurdity, alienation, anguish and disgust in the existential philosophy of Jean-Paul Sartre, Albert Camus, Karl Gaspers and Gabriel Marcel have established a philosophical basis for the modern Theatre of the Absurd.

\section{Betrayal - The Play}

In Betrayal, Harold Pinter shows that men are betrayed not only by men, but by time - a recurring theme which has finally found its proper scenic correlative in the play. Pinter's narrative method takes "what's next?" out of the spectator's mind and replaces it with the rather deeper "how"? and "why"? Why did love pass? How did these people cope with the lies, the evasions, the sudden dangers, the panic, the risk, and the contradictory feelings behind their self-created masks? The play's subject is neither sex nor adultery, but the politics of betrayal and the damage it inflicts on all involved. In Pinter's Betrayal, Robert has affairs, but is married with two children. So is his best friend Jerry. Yet Jerry is also having an affair with Robert's wife, Emma. They have been at it for seven years, even sharing a flat. Nor is it a secret. At a certain point in time, everyone knows, but not everyone knows who knows. Pinter acknowledges how people manage the tensions around emotional security and romantic yearnings. There is no terrifying climax, no make or break confrontation. Not that there isn't pain, jealousy, loss and anger, but when everyone is guilty of some betrayal, it almost ceases to be an accusation.

In his play, Betrayal, the truth about its characters is approached by reversing the chronological order 1977 to 1968 -, in which their actions are viewed, a stratagem that critics find apt, considering Pinter's concern with memory. A characteristic Pinteresque drama is marked by its evocation of terror amid farcical business and sometimes fanciful dialogue. Typically, Pinter's characters seek security, self-identification and verification of truth but find communication virtually impossible. Instead, there are pathetic games, clichés, long silences, sinister threats and impending dangers, all presented in suspenseful plots.

In Katerina Vassilopoulou's view, the readers of absurdist plays are faced with a world that is similar to theirs, but all their expectations for a realistic plot are then disrupted [2]. This disruption is further reinforced by the characters' unexpected reaction to the impossibilities. Their attitude in no way accords with the way one would react in the real world, as characters do not appear to hold the same assumptions as the readers about the 
laws that govern their world. As a consequence, any attempt on the readers' part to construct a coherent text world is frustrated. A crucial factor for the creation of absurdity is the fact that the inter-world conflicts do not lead to the undertaking of action that will move the plot forward. As regards the role of internal conflicts of fictional worlds, in Pinter's Betrayal the characters hold conflicting knowledge worlds and by the time the play ends conflict remains unresolved.

Betrayal (1978) features Pinter's characteristically economical dialogue, character's hidden emotions and veiled motivations, and their self-absorbed competitive one-upmanship, face-saving, dishonesty and (self-) deceptions. The plot of Betrayal exposes different permutations of betrayal and kinds of betrayal occurring over a period of nine years, relating to a seven-year affair involving a married couple, Emma and Robert, and Robert's close friend Jerry, who is also married to a woman named Judith. For five years Jerry \& Emma carry on their affair without Robert's knowledge, both cuckolding Robert and betraying Judith, until Emma, without telling Jerry she has done so, admits her infidelity to Robert (in effect, betraying Jerry), although she continues their affair. In 1977, four years after exposing the affair ( in 1973) and two years after their subsequent break up ( in 1975) , Emma meets with Jerry to tell him that her marriage to Robert is over. She then lies to Jerry in telling him that, 'last night', she had to reveal the truth to Robert and that he now knows of the affair. The truth, however, is that Robert has known about the affair for the past four years.

\section{Reverse Chronology Of The Plot}

Pinter's particular usage of reverse chronology in structuring the plot is innovative: the first scene takes place after the affair has ended, in 1977, the final scene ends when the affair begins in 1968; and in between 1977 and 1960 scenes in two pivotal years (1977 and 1973) move forward chronologically. Roger Ebert observes that the structure of the play strips away all artifice. It shows, heartlessly, that the very capacity for love itself is sometimes based on betraying not only other loved ones, but even ourselves.

In 1975, Jerry and Emma decide to give up the flat they have rented for their afternoon assignations, thereby ending the affair; their passion appears to have fizzled out. This is shown in Scene Three of the play:

EMMA

It's a waste. Nobody comes here. I just can't bear to think about it, actually. Just ... empty. All day and night. Day after day and night after night. I mean the crockery and the curtains and the bedspread and everything. And the tablecloth I brought from Venice. (Laughs). It's ridiculous.

It's just ... an empty home.

JERRY

It's not a home.

Pause

I know ... I know what you wanted ... but it could never ... actually be a home. You have a home. I have a home. With curtains, etcetera. And children. Two children in two homes. There are no children here, so it's not the same kind of home. [3]

And later in the scene, their decision of separation is further emphasised:

EMMA

... Silence. She puts coat on.

I'm going now.

He turns, looks at her.

... I'm picking up Charlotte from school. I'm taking her shopping.

... Do you realise this is an afternoon? It's the Gallery's afternoon off. That's why I'm here. ... Thanks.

Listen. I think we've made absolutely the right decision.

She goes.

He stands. [3]

As it is seen here, in Scene Three, of the play, Emma takes the decision of walking out of her relationship with Jerry all on a sudden and abruptly informs him of it, leaving Jerry and the audience/ reader in a state of shock. Though Jerry does not seem to be quite happy with the decision, he does not oppose it in a strong way. He lets her have her way without making any fuss about it. Perhaps, he did not want to impose anything on her. The affair which had continued so steadily for several years seemed to have come to a strange end. May be, it is this strangeness and absurdity of human relationships that constitutes the reality of life. Hence, the depiction of absurdity of life can be a means of representing the reality of human existence.

In the last scene, while alone at party in Robert and Emma's house, Jerry drunkenly declares his feelings for Emma in the latter's bedroom. It is very strange to note that the play ends with Jerry's confession of his love for Emma. It was this confession that initiated the primary betrayal episode in the play. Hence, the play seems to end in a very absurd way. By disrupting the chronology of events, Pinter tries to narrate a story of betrayal in an unconventional way. Perhaps, this is how stories are registered in the human mind and this is how they become part of human memory. It appears as though the play is a rendering of the author's memory. And 
recollection of events on the basis of memory leads one to recall them retrospectively in a non-chronological order.

'Absurd' basically means out of harmony with reason or propriety; incongruous, unreasonable, illogical. In modern sense, it is plainly opposed to reason, and hence, ridiculous, silly. But this is not the sense in which it is used when we speak of the Theatre of the Absurd. In the Theater of the Absurd (1964) Esslin writes that the human condition is presented to us as a concrete poetic image that has become flesh on the stage and that is at the same time broadly comic and deeply tragic.

Pinter's Betrayal is marked by daring time-reversal of its plot, the supremacy of its abstract shape over its narrative content, its position on the relevance of time to memory, its dispassionate, ironic tone, and its deliberate avoidance of a moral stance. The chronological reversal is instrumental to this general shake-up of the dramatic form and style. The characters' incessant search for meaning is shared by the spectator/reader but is deflected, through the sophisticated formal shaping elements employed by Pinter, from the ethical to the aesthetic sphere. The play has been analyzed by scholars as an experiment in abstraction, a presentation of human relationships in terms of game sequences, and a post-modern, aesthetic and ironic treatment of what used to belong to religion and ethics. The very title of the play, Betrayal without any article, whether definite or indefinite, indicates that the play has to do with the idea of betrayal, its generalized or abstracted structure, and not the story of one particular instance of betrayal. The title refers to the betrayal of love and friendship and the word, 'Betrayal' points to its inherently negative emotive and ethical connotations in our society. Betrayal involves three characters in a romantic tangle. In his presentation of this romantic triangle, Pinter is interested not so much in the love affairs as in its complementary betrayal. He thus shifts the focus from the new love to the betrayal of the old love, from romanticism to disillusion. The romantic triangle is obviously a hackneyed theme, but Pinter's variations on it, in Betrayal are highly innovative. In the view of Martin Esslin, Pinter presents us with a symphonic structure of variations on the theme of betrayal that, ultimately, becomes an inquiry into the inextricable web of lies that constitutes the social relationships.

\section{Relationship Between Time And Memory}

The relationship between time and memory takes on a different aspect in Betrayal through the playwright's decision to reverse the chronological order or events. This startling reversal of the progression of the plot as function of time takes us back from the dissolution of both the love affair and the marriage in 1977 to Jerry's opening gambit of the betrayal, in Robert \& Emma's bedroom, in 1968. The banality of the romantic triangle is turned inside out through the reversal of the normal plot sequence. Every new scene of the play turns out to be unexpected because, although we know the outcome, we don't know what the steps that led up to it were. By the beginning of the play, everything we shall witness has already been, as it were, predetermined. The betrayal game has been concluded and all that remains is to watch the moves that brought about the result. This is the most innovative aspect of Pinter's engagement with the theme of betrayal in the play. It is really a painstaking unravelling of the sequence of events that make up the betrayal and a deconstruction of its conceptual components. The movement back in time may seem at first artificial because we, as readers/ theatregoers are in the habit of viewing the dramatic plot as a function of the time axis. But from the perspective of memory, all stories are terminated processes viewed from the vantage point of the present, so that unfolding a series of events in reverse temporal order may be, experientially the more natural procedure.

Pinter has written this play in an unusual way. Its actions move from the latter to the former ; ( i.e. the play began in the year 1977 and ended in 1968). Pinter said that the most effective way to handle this play was by disrupting the temporal order of occurrence of events. I agree with him because if it moved normally from the oldest to the latest it would not have been that interesting.

What is absolutely astonishing in the play is the way Robert reacts to his wife's confession of infidelity. He tells her, just before her disclosure of betrayal to him, that he discovered the matter the day before when he saw, though not read, the letter sent to her by Jerry. This is revealed in Scene Five of the play:

\section{ROBERT}

Yesterday. Only yesterday. When I saw his handwriting on the letter. Before

yesterday I was quite ignorant.

EMMA

...I'm sorry.

ROBERT

...Where does it... take place? Must be a bit awkward. I mean we've got two

kids, he's got two kids, not to mention a wife ...

EMMA

We have a flat.

ROBERT

Ah. I see. [3] 
Robert's casual behaviour in such a situation is quite disturbing to the audience. Thus, the play leaves us restless and dumbfounded. Perhaps, human life itself is mysterious like that. And hence Pinter projects the mystery of life in such a way which only seems absurd.

of his love to Emma in

The play, Betrayal ends in an absurd way. It ends nine years ago in 1968 with Jerry's confession

Scene Nine in Robert and Emma's bedroom:

JERRY

“... I can't wait for you, I'm bowled over, I'm totally knocked out, you dazzle me, ... my jewel, I can't ever sleep again, no, listen, it's the truth, I won't walk, I'll be a cripple, I'll descend, I'll diminish, into total paralysis, my life is in your hands, that's what you're banishing me to, a state of catatonia, do you know the state of catatonia? do you? do you? the state of... where the reigning prince is the prince of emptiness, the prince of absence, the prince of desolation. I love you."

... EMMA moves towards the door. JERRY grasps her arm.

She stops still..

They stand still, looking at each other. [3]

\section{Conclusion}

Thus, the play comes to an abrupt end. What is shown in the last scene of the play is something which is chronologically supposed to take place in the beginning. The sequence of events in the play occurs over a period of nine years - 1968 to 1977 - and strangely enough, the play begins in 1977 with Emma's decision to get divorced from her husband Robert, while it ends in 1968 with Jerry's passionate declaration of his love for his best friend Robert's wife, Emma whose reciprocation to the proposal triggers off the main 'betrayal' episode in the play. Hence, what we see is that the climax is presented to us in the very beginning of the play and what leads to the climax comes only in the end. The playwright deliberately seems to disrupt the chronological order of the play. Perhaps, the disconnected situations presented to us in the play suggest a certain way of looking at reality. May be, this is how we reconstruct reality when we make an attempt to recall it on the basis of memory. If we look at a certain chain of events retrospectively, we normally tend to begin the process of recollection from the vantage point of the present. And therefore moving gradually back in time, in the course of recreating reality in such a way by relying on memory, seems quite natural. Betrayal is a text which invites the reader/ spectator to make meaning for themselves. The text is a site for the uncontrollable play of signifiers, and hence, there is an infinite deferral of meaning; there is no ultimate signified to guide the quest for meaning.

\section{References}

[1] Abrams, M.H. A Glossary of Literary of Literary Terms. Sixth Edition. Bangalore: Prism Books, 1993.

[2] Vassilopoulou, Katerina. "Possible worlds in the theatre of the absurd." Lancaster University Post Graduate Conference in Linguistics and Language Teaching. Vol. 1. Costas Gabrielatos, Richard Slessor and J.W.Unger ed. Lancaster: Lancaster University, 2007.

[3] Pinter, Harold. Betrayal. London: Faber and Faber, 1978. 